\title{
The Effect of Altered Sodium Balance upon Renal Vascular Reactivity to Angiotensin II and Norepinephrine in the Dog
}

\author{
MECHANISM OF VARIATION IN ANGIOTENSIN RESPONSES
}

\author{
Juan A. Oliver and Paul J. Cannon, Department of Medicine, College of \\ Physicians and Surgeons, Columbia University, New York 10032
}

A B S T RACT The mechanism whereby the vasoconstrictor response to angiotensin II $\left(\mathrm{A}_{\mathrm{II}}\right)$ is influenced by sodium balance or disease is unclear. To explore this question, the renal vascular responses (RVR) to intrarenal injections of subpressor doses of $\mathrm{A}_{\mathrm{II}}$ and norepinephrine were studied in dogs with an electromagnetic flowmeter. Acute and chronic sodium depletion increased plasma renin activity (PRA) and blunted the RVR to $A_{I I}$, while acute sodium repletion and chronic sodium excess plus desoxycorticosterone acetate decreased PRA and enhanced the RVR to $A_{I I}$. The magnitude of the RVR to $A_{I I}$ was inversely related to PRA. The RVR to norepinephrine was unaffected by sodium balance and was not related to PRA. Inhibition of the conversion of angiotensin I to $A_{\text {II }}$ by SQ 20,881 during sodium depletion lowered mean arterial blood pressure (MABP), increased renal blood flow (RBF), and enhanced the RVR to $A_{\text {II }}$ but not to norepinephrine. Administration of bradykinin to chronically sodium-depleted dogs also lowered the MABP and increased RBF but had no effect on the RVR to $A_{I I}$. SQ 20,881 had no effect on MABP, RBF, or the RVR to $A_{I I}$ in the dogs with chronic sodium excess and desoxycorticosterone acetate. Administration of indomethacin to chronically sodium-depleted dogs lowered RBF but did not influence the RVR to $A_{I I}$.

The results indicate that the RVR to $A_{I I}$ is selectively influenced by sodium balance and that the magnitude of the response is inversely related to the availability of endogenous $A_{\text {II }}$. The data did not suggest that the variations in the RVR to $A_{I I}$ were because of direct effects of sodium on vascular contraction, changes in

Received for publication 8 August 1977 and in revised form 14 November 1977. the number of vascular $A_{\text {II }}$ receptors, or the renal prostaglandins. The results are consistent with the hypothesis that the vasoconstrictor effect of $A_{I I}$ in the renal vasculature is primarily dependent upon the degree to which the $A_{I I}$ vascular receptors are occupied by endogenous hormone.

\section{INTRODUCTION}

Changes in sodium balance are a major stimulus regulating the activity of the renin-angiotensin system. During sodium depletion, there is an increase in the concentration of circulating angiotensin II (1). The administration to sodium-depleted animals or to humans of pharmacological agents that prevent the formation of angiotensin II $\left(\mathrm{A}_{\mathrm{II}}\right)^{1}$ or that compete with this polypeptide for its vascular receptors, induces a drop in arterial blood pressure with little or no change in cardiac output (2-5). Despite the fact that the vasoconstrictor action of $A_{11}$ appears to be essential for the maintenance of normal blood pressure during sodium depletion, the pressor and vascular responses to exogenously administered octapeptide are greatly reduced in this condition (6-12). Conversely, there is an enhancement of the pressor and vascular responses to $A_{I I}$ in situations of sodium excess $(7-9,12)$. Differences in the pressor responsiveness to $A_{\text {II }}$ have also been reported in a variety of diseases including cirrhosis with ascites (9, 13, 14), nephrosis (14), malignant and renovascular hypertension (7), Bartter's syndrome $(15,16)$, and Addison's disease (17). The mechanisms underlying these variations have not been clarified.

\footnotetext{
${ }^{1}$ Abbreviations used in this paper: $\mathrm{A}_{\mathrm{l}}$, angiotensin $\mathrm{I}$; $A_{I I}$, angiotensin II; CEI, converting enzyme inhibitor; DOCA, desoxycorticosterone acetate; PRA, plasma renin activity.
} 
Four major hypotheses have been proposed to explain the inverse relationship between the state of sodium balance and the magnitude of the vascular response to $\mathrm{A}_{\mathrm{II}}:(a)$ that sodium has a direct effect upon the contractile response of vascular smooth muscle induced by $A_{11}(9,11,18)$, $(b)$ that the vasoconstrictor response to exogenous $A_{\text {II }}$ is inversely related to the degree to which the vascular $A_{I I}$ receptors are occupied by endogenous polypeptide $(6,19),(c)$ that the concentration of $A_{I I}$ receptors in vascular smooth muscle is variable and that this concentration determines the vascular response to the hormone $(20)$, and $(d)$ that the vasoconstriction produced by $\mathrm{A}_{\mathrm{II}}$ is modulated by the concomitant vasodilator action of other hormones with opposing effects (e.g., prostaglandins) (21).

The present study was designed: (a) to characterize the effect of changes in sodium balance upon the renal vascular reactivity to $A_{I I}$ and to norepinephrine, and $(b)$ to test the hypothesis that variations in the renal vascular response to $A_{I I}$ result from competition between endogenous and exogenous hormone for the same vascular receptors. The renal vasculature was chosen for study because blood flow responses to injections of $A_{I I}$ into the renal artery can be elicited without alterations in systemic hemodynamics and because endogenous levels of renin and $\mathrm{A}_{\text {II }}$ are higher in the kidney than in the general circulation (22).

The renal blood flow responses to injections of exogenous $A_{I I}$ and norepinephrine into the renal artery were measured in anesthetized dogs in which the endogenous activity of the renin-angiotensin system had been altered by inducing acute or chronic alterations of sodium balance.

In other experiments, the amount of endogenous $A_{I I}$ available was reduced by the administration of the synthetic nonapeptide, L-Pyroglutamic acid(Pyr)Trp-Pro-Arg-Pro-Gln-Ile-Pro-Pro (SQ 20,881), which blocks the conversion of angiotensin $I\left(A_{I}\right)$ to $A_{I I}$ by inhibiting the angiotensin-converting enzyme (23). In this manner, the effect of a decrease in endogenous $A_{I I}$ on the renal vascular responses to $A_{I I}$ and norepinephrine was examined in the absence of a change in the balance of sodium.

Finally, studies of renal vascular reactivity to the two hormones were performed before and after administration of the inhibitor of prostaglandin sinthetase, indomethacin.

The results of the studies confirm that changes in sodium balance selectively alter the renal vascular responses to $A_{I I}$ and that $A_{I I}$ contributes to the control of renal vascular tone during sodium depletion. Moreover, the data provide evidence that the varied renal blood flow responses to $A_{I I}$ observed in different states of sodium balance result primarily from a competition between endogenous and exogenous hormone for the same vascular receptors so that diminished flow responses occur when the vascular receptors are occupied by endogenous octapeptide.

\section{METHODS}

\section{Experimental animals}

The experiments were performed with 37 female mongrel dogs, weighing $15-25 \mathrm{~kg}$, that were maintained in three different states of sodium balance: (a) 13 animals were maintained on a normal chow diet (Respond 2,000, Agway Country Foods, Agway, Inc., Syracuse, N. Y.) which provided a sodium intake of $80-100$ meq per day. (b) Dietary sodium depletion was induced in 19 dogs by the injection of $10 \mathrm{mg}$ of furosemide intramuscularly 9 and 10 days before study followed by administration of a diet $(h / d$ diet, Riviana Foods Inc., New York) which provided less than $5 \mathrm{meq}$ of sodium per day. This resulted in a weight loss from $22.0 \pm 0.6$ to $21.1 \pm 0.6 \mathrm{~kg}$ (mean $\pm \mathrm{SE} ; P<0.001)$; the mean urinary sodium concentration in these animals was 5.2 $\pm 1.5 \mathrm{meq} / \mathrm{liter}$ (mean $\pm \mathrm{SE}$ ) on the day of the study. (c) $\mathrm{A}$ positive sodium balance was produced in five dogs by administration of $10 \mathrm{mg}$ of desoxycorticosterone acetate (DOCA) intramuscularly each day for 8-10 days before study and by supplementing the normal chow diet with $15 \mathrm{~g}$ of salt daily $\left(258 \mathrm{meq} \mathrm{Na}^{+}\right)$. The weight of these dogs increased slightly from $21.9 \pm 1.0$ to $22.6 \pm 0.7 \mathrm{~kg}$ (NS). On the day of study their mean urinary sodium concentration was $142 \pm 22 \mathrm{meq} / \mathrm{liter}$. Tap water was allowed ad libitum to all dogs.

\section{Experimental preparation}

Anesthesia was induced with intravenous pentobarbital sodium $(30 \mathrm{mg} / \mathrm{kg})$ and maintained with periodic additional doses. After cannulation of the trachea, the dogs were ventilated with a positive pressure respirator (Harvard Apparatus Co., Inc., Millis, Mass.). The urinary bladder was catheterized with a Foley catheter for urine collection. Arterial blood pressure was monitored from a polyethylene catheter placed in the right femoral artery with a P23 Db Statham pressure transducer (Statham Instruments, Inc., Oxnard, Calif.) and was recorded continuously on a model 7 polygraph (Grass Instrument Co., Quincy, Mass.). For measurement of cardiac output, $1.4 \mathrm{ml}$ of indocyanine (cardiogreen) dye solution containing $2.5 \mathrm{mg} / \mathrm{ml}$ of dye was injected into the right atrium via a catheter in the right jugular vein. Arterial blood was withdrawn via a catheter in the left femoral artery through a densitometer (Gilford Instrument Laboratories Inc., Oberlin, Ohio, model 103 IR) at $15 \mathrm{ml} / \mathrm{min}$. After recording the curves on a strip chart recorder (680 M, Hewlett-Packard Co., Palo Alto, Calif.), the blood was reinfused into the animal. The densitometer was calibrated at the end of each experiment with blood containing dye concentrations within the range of those obtained during the study. Cardiac output was calculated by standard methods and each measurement represents an average of two or three dye dilution curves. The urinary sodium concentration was measured by flame photometry (Instrumentation Laboratory Inc., Lexington, Mass., model 143). Plasma renin activity (PRA) in arterial blood was measured by the method of Sealev et al. (24).

For measurement of renal blood flow, the left kidney was exposed by a flank incision and a noncannulating electromagnetic flow probe of appropriate diameter was placed on the renal artery. Output from the flowmeter 
(Carolina Medical Electronics, Inc., King, N. C., model 501) was continuously recorded on the Grass polygraph. Zero flow was determined by a brief occlusion of the renal artery distal to the probe immediately after its application and at the end of the experiment. At least $1 \mathrm{~h}$ was allowed to elapse after surgery before making control measurements.

To test the reactivity of the renal vasculature to the pressor agents, a small tygon catheter (outside diameter $=1.016 \mathrm{~mm}$, inside diameter $=0.610 \mathrm{~mm}$ ) was inserted into the left renal artery proximal to the flow probe by the method of Herd and Barger (25). The lumen of the catheter was kept patent by an infusion of isotonic saline at $0.04 \mathrm{ml} / \mathrm{min}$ with a Harvard infusion pump (Harvard Apparatus Co., Inc.). Doses of $A_{I I}$ (Hypertensin, Ciba Corp., Summit, N. J.) and norepinephrine (Levophed, Winthrop Labs., Div. of Sterling Drug, New York) were dissolved in $0.5 \mathrm{ml}$ of $0.9 \%$ saline for administration into the renal artery through the catheter. In preliminary experiments, constant intrarenal infusions of $\mathrm{A}_{\mathrm{II}}$ or norepinephrine did not induce steady-state changes in renal blood flow, confirming observations reported by others (21). Both hormones, therefore, were administered as single bolus injections by increasing the Harvard pump infusion rate to $0.4 \mathrm{ml} / \mathrm{min}$. Recovery periods of $5-15 \mathrm{~min}$ were allowed between doses and the sequence of administration was varied randomly. The maximal renal blood flow change induced by each dose was chosen as the indicator of the renal vascular response; this usually occurred $5-15 \mathrm{~s}$ after the administration of the hormones.

In the studies with the converting enzyme inhibitor (CEI), a dose of $0.25 \mathrm{mg} / \mathrm{kg}$ of $\mathrm{SQ} 20,881$ dissolved in 10 $\mathrm{ml}$ of saline was administered intravenously. The degree to which this dose inhibited the conversion of $A_{1}$ to $A_{11}$ was assessed in six dogs with dietary sodium depletion by measuring the response of arterial blood pressure during 5 -min intravenous infusions of $A_{I}(0.4 \mu \mathrm{g} / \mathrm{kg}$ per min) before and after administration of CEI. During the control period, $A_{I}$ increased mean arterial blood pressure by $45 \pm 11 \mathrm{~mm} \mathrm{Hg}$ (mean $\pm \mathrm{SE}$ ) while after CEI the same dose of $\mathrm{A}_{1}$ increased arterial blood pressure by only $19 \pm 4 \mathrm{~mm} \mathrm{Hg}(P<0.02)$. In contrast, the pressor effect of $A_{I I}$ increased after CEI from $2: 3 \pm 3 \mathrm{~mm} \mathrm{Hg}$ in the control period to 4()$\pm 7 \mathrm{~mm} \mathrm{Hg}$ $(P<0.02)$

\section{Specific protocols}

\section{PROTOCOL 1-NORMAL SODIUM DIET: ACUTE NATRIURESIS; CEI ADMINISTRATION}

After anesthesia, the 13 dogs on a normal diet were given an infusion of Ringer's lactate equal to $2 \%$ of body weight to compensate for surgical losses, followed by a similar sustaining infusion at $0.1 \mathrm{ml} / \mathrm{kg}$ per min. Control measurements of systemic and renal hemodrnamics were made and the intrarenal injections of graded doses of $A_{11}(0.31-10$ $\mathrm{ng} / \mathrm{kg}$ ) and norepinephrine $(3.2-32 \mathrm{ng} / \mathrm{kg}$ ) were carried out. Each animal was then given $20 \mathrm{mg}$ of furosemide intravenously and the sustaining infusion of Ringer's lactate solution was discontinued. Immediately after the administration of furosemide, there was a transient increase in renal blood flow. After 50-60 min, during which diuresis occurred in all and renal blood flow stabilized, the hemodrnamic measurements and intrarenal injections of the two pressor hormones were repeated. Finally, CEI was administered intravenousls and $5-10$ min later a third series of measurements and intrarenal injections of $A_{11}$ and norepinephrine was performed. During each experimental period and before any experimental mancuver, blood was drawn for PRA determination.

\section{Protocol 2-Dietary SODIUM DEPLETION}

Protocol 2a-Converting enzyme inhibition. Six dogs with dietary sodium depletion were used in this experiment. After base-line hemodynamic determinations, the doses of $A_{I I}$ and norepinephrine were injected into the renal artery. Next, CEI was administered intravenously as a bolus 5-10 min later, intrarenal injections of $A_{I I}$ and norepinephrine were repeated.

Protocol $2 \mathrm{~b}-$ Bradykinin administration. In addition to blocking the conversion of $A_{1}$ to $A_{I I}$, CEI may increase the concentration of circulating and urinary kinins (26). $\mathrm{T}_{0}$ exclude the possibility that changes in the renal vascular reactivity after CEI might be due to an increase in bradykinin, intrarenal $A_{I I}$ and norepinephrine injections were carried out in six other dogs with dietary sodium depletion before and during administration of bradykinin. Bradykinin (Sigma Chemical Co., St. Louis, Mo.) was dissolved in saline and administered intravenously at a constant rate. The dose of bradykinin administered was variable for different dogs (range 0.16 to $8 \mu \mathrm{g} / \mathrm{kg}$ per min), but was constant in each animal. It was determined by inducing an increase in the renal blood flow and a decrease in the mean arterial pressure of similar magnitude to those observed after administration of CEI (vide supra).

PROTOCOL 2c-Acute sodium repletion. Since bradykinin has a half-life of about $16 \mathrm{~s}$ in dog's blood (27), the bradykinin-infused dogs were utilized for another experimental maneuver. After discontinuation of bradykinin, when mean arterial pressure and renal blood flow returned to the control values observed before its infusion, a loading dose of Ringer's lactate solution equal to $5 \%$ of the dog's body weight was administered intravenously over a 30 - to $45-\mathrm{min}$ period. This was followed by a sustaining infusion at 0.2 $\mathrm{ml} / \mathrm{kg}$ per min at which time the intrarenal injections of $A_{I I}$ and norepinephrine were repeated. In these animals, the data obtained after the sodium repletion with Ringer's lactate solution were compared to those obtained during the control state of dietary sodium depletion (i.e., before the bradykinin infusions).

\section{ProTOCOL 3-HIGH SODIUM DIET AND DOCA DOGS: CEI ADMINISTRATION}

After anesthesia, the five dogs which had received a high sodium intake and DOCA were given a continuous intravenous infusion of Ringer's lactate at $0.2 \mathrm{ml} / \mathrm{kg}$ per min. Measurements of systemic and renal hemodynamics and the renal responses to intrarenal $A_{I I}$ and norepinephrine injections were performed in these animals before and after the intravenous administration of $0.25 \mathrm{mg} / \mathrm{kg}$ of CEI.

\section{PROTOCOL 4-INDOMETHACIN ADMINISTRATION}

In seven dogs with dietary sodium depletion, the effect of the administration of the cyclo-oxygenase inhibitor, indomethacin (28), upon the renal vascular responsiveness to $\mathbf{A}_{I I}$ and norepinephrine was examined. Indomethacin was dissolved in about $2 \mathrm{ml}$ of $95 \%$ ethanol and diluted 20)-fold in Kreb's solution (pH 7.4). This solution was injected intravenously over a 2 -min period. The dose of indomethacin utilized $(2 \mathrm{mg} / \mathrm{kg})$ has been established as adequate to block the release of renal prostaglandins (29).

\section{Statistical analysis}

To determine the relationship between the change in renal blood flow induced by $A_{I I}$ and norepinephrine and the 
base-line level of renal blood flow, an analysis of covariance was performed with the base-line renal blood flow as the covariant (30). Since in no case was there a significant relationship between these variables, the absolute level of change in blood flow in milliliters per minute, without correction for the base-line flow or normalization, as percentages, was used as the variable of interest. Subsequently, the data were analyzed by an analysis of variance in which the state of the animal (e.g., sodium depletion and CEI administration) was used as one criterion and the dose of the hormone was the other criterion (30). In this manner, dose-response curves for $A_{11}$ and norepinephrine in each state were constructed and compared. The mean overall responses were calculated as the average of all doses. When applicable, data were analyzed by Student's $t$ test for paired or unpaired observations. All values are expressed as mean \pm SEM. Changes were termed significant if the $F$ value or $t$ value exceeded the $5 \%$ level (30).

\section{RESULTS}

\section{Effect of chronic changes in sodium balance on renal vascular reactivity}

Figs. 1-3 summarize and compare measurements made during control periods in all of the animals maintained on different sodium intakes. The mean PRA was significantly different in the three groups; $20.2 \pm 3.8 \mathrm{ng} / \mathrm{ml}$ per $\mathrm{h}$ in the sodium-deprived animals, $1.8 \pm 0.3 \mathrm{ng} / \mathrm{ml}$ per $\mathrm{h}$ in those on a normal diet, and $0.11 \pm 0.04 \mathrm{ng} / \mathrm{ml}$ per $\mathrm{h}$ in those receiving a high sodium intake and DOCA (Fig. 1). Mean arterial blood pressure of the sodium-depleted dogs was not different from that of the animals fed a normal diet; however, cardiac output was significantly lower and total peripheral vascular resistance was increased. The renal blood flow was also significantly reduced and renal vascular resistance was increased in the sodiumdepleted dogs. The mean arterial pressure, cardiac output, and renal hemodynamics of the animals given a high salt intake and DOCA were not significant from those of the control animals (Fig. 1).

Fig. 2 depicts the dose-response curves of the intrarenal injections of $A_{I I}$ and norepinephrine for the three groups of animals. In none of these or subsequent studies was arterial blood pressure changed by the intrarenal hormone injection. The renal vascular responses to $A_{I I}$ were smaller in the sodium-
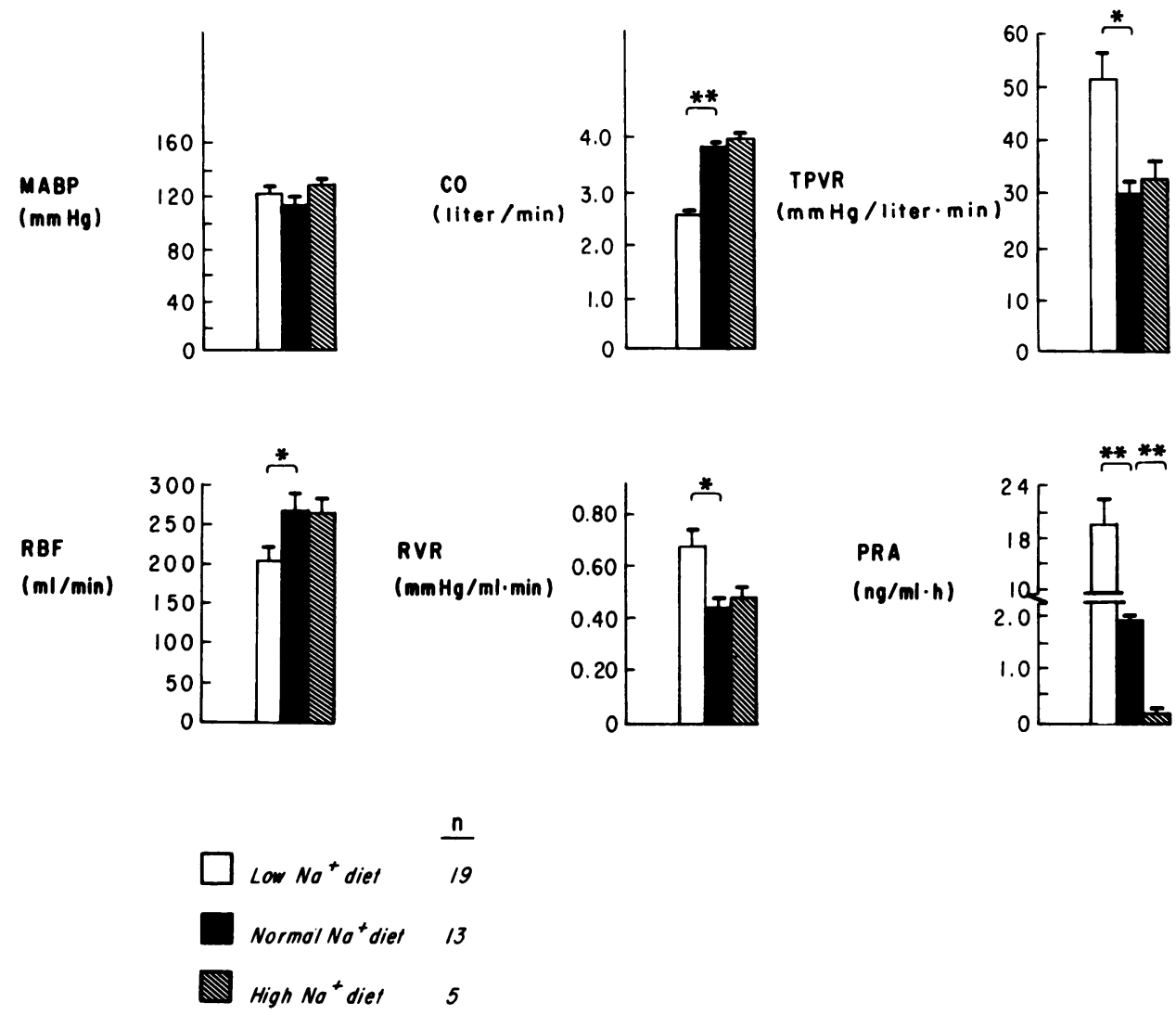

FIGURE 1 Influence of $\mathrm{Na}^{+}$balance on systemic and renal hemodynamics and PRA. Vertical lines indicate mean \pm SE. MABP, mean arterial blood pressure; CO, cardiac output; TPVR, total peripheral vascular resistance; $R B F$, renal blood flow; RVR, renal vascular resistance; PRA, plasma renin activity. ${ }^{*}$ Indicates $P<0.05$ and ${ }^{* *}, P<0.005$. PRA in normal $\mathrm{Na}^{+}$diet $n=9$. 


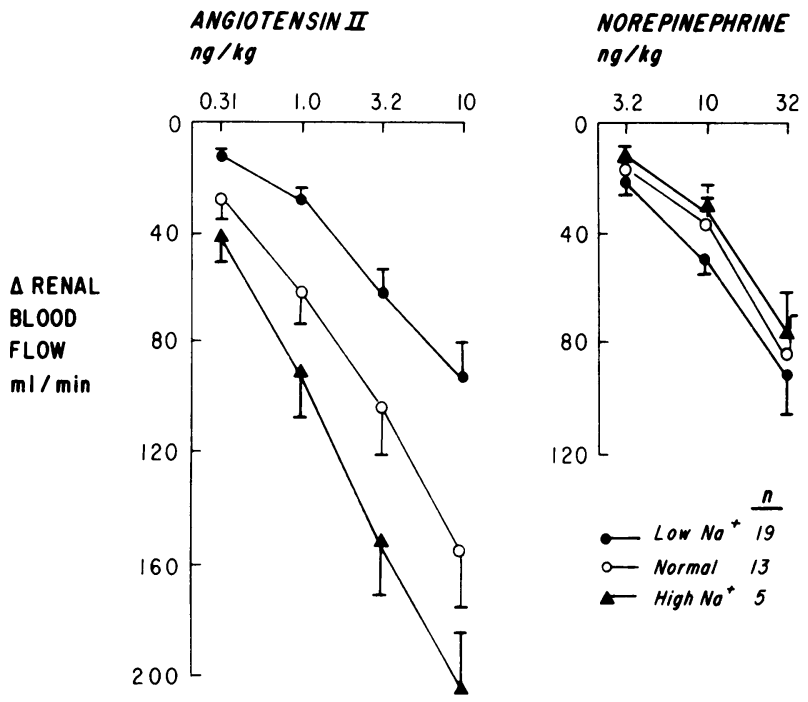

Figure 2 Influence of $\mathrm{Na}^{+}$balance on the renal vascular response to $A_{I I}$ and norepinephrine. Vertical lines indicate mean $\pm \mathrm{SE}$.

depleted dogs, intermediate in the dogs fed a normal diet, and larger in the animals given a high salt diet and DOCA. The mean overall renal blood flow response induced by $A_{I I}$ in the sodium-depleted dogs was $50 \pm 6 \mathrm{ml} / \mathrm{min}$, significantly lower than the value of $87 \pm 13 \mathrm{ml} / \mathrm{min}$ found in the normal dogs (Fig. 3). For the high salt-DOCA dogs, the mean overall effect of $A_{11}$ was $122 \pm 16 \mathrm{ml} / \mathrm{min}$ (Fig. 3).

Fig. 2 shows that the dose-response curves for norepinephrine were not significantly different in the three groups of animals maintained on different

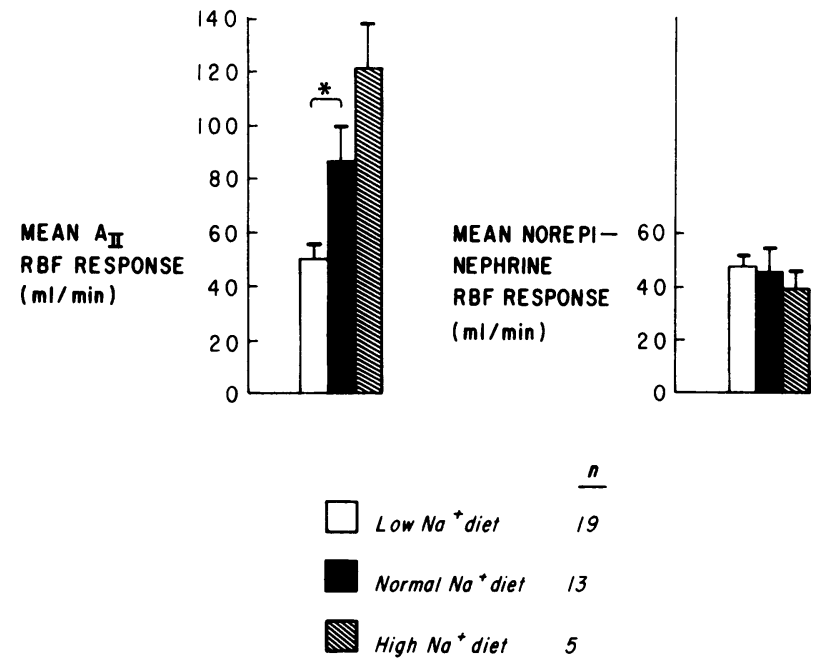

FIgURE 3 Influence of $\mathrm{Na}^{+}$balance on the mean overall renal vascular response to $A_{I I}$ and norepinephrine. Vertical lines indicate mean $\pm S E$. * Indicates $P<0.05$. sodium regimens. The mean overall renal blood flow response to norepinephrine was $46 \mathrm{ml} / \mathrm{min}$ in the dogs fed a normal sodium diet, $47 \mathrm{ml} / \mathrm{min}$ in the sodium-depleted dogs, and $39 \mathrm{ml} / \mathrm{min}$ in the high saltDOCA group (differences NS) (Fig. 3).

The relationship between PRA and the renal vascular response to $A_{I I}$ in each animal was examined across groups. Fig. 4 shows that there was a significant correlation between the PRA and the renal blood flow response to $\mathrm{A}_{\mathrm{II}}(r=0.594, \quad P<0.001)$. A similar analysis for norepinephrine responsiveness is also shown in Fig. 4. Unlike $A_{\text {II }}$, the mean renal blood flow response to norepinephrine was not significantly related to the PRA $(r=0.058, \mathrm{NS})$.

\section{Effect of acute changes in sodium balance on renal vascular reactivity}

Acute sodium depletion. To determine the effect of acute sodium depletion on the renal vascular response to $A_{I I}$ and norepinephrine, acute natriuresis
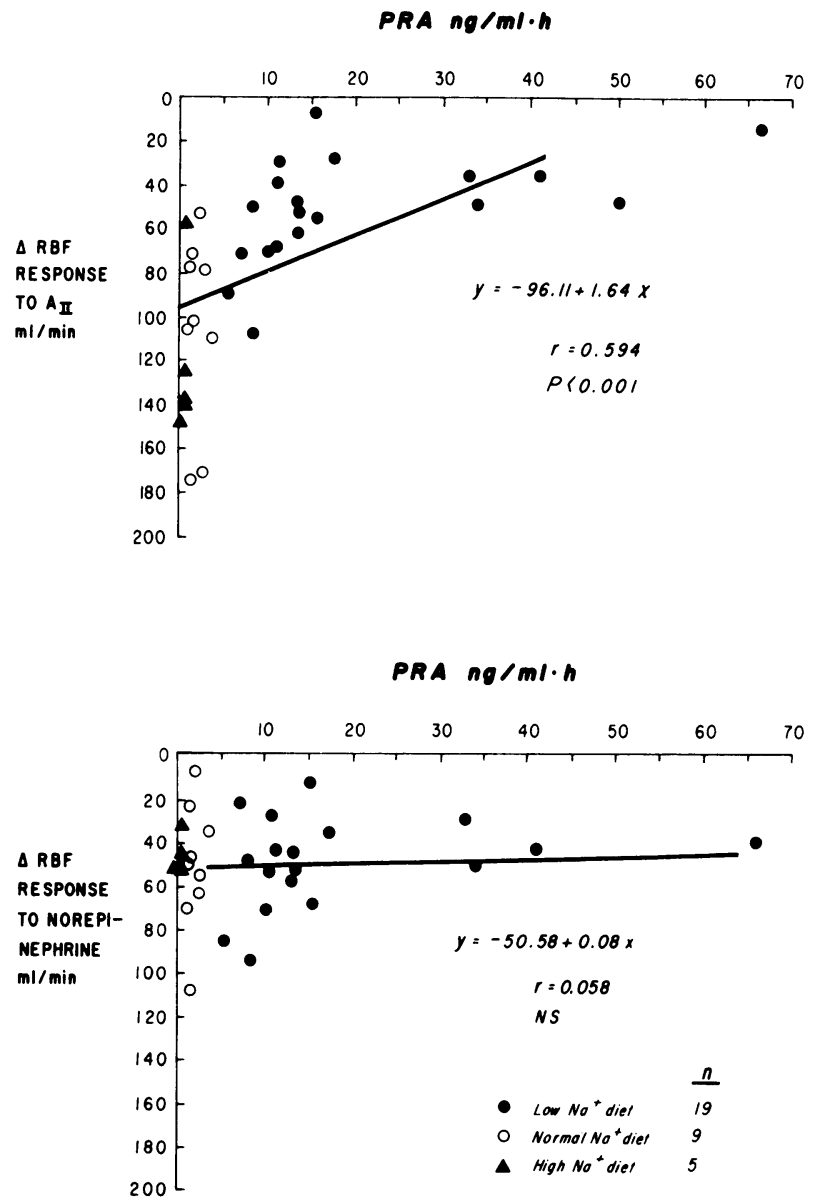

Figure 4 Regression relationships between PRA and the renal blood flow response to $A_{\text {II }}$ and norepinephrine. 
was induced in the dogs fed normal diets by the administration of furosemide. As indicated in Table IA, diuresis resulted in a significant rise in hematocrit and a proportionally greater rise in PRA from 1.8 to $14.4 \mathrm{ng} / \mathrm{ml}$ per $\mathrm{h}(P<0.01)$. Cardiac output declined significantly and there was a significant increase in total peripheral vascular resistance; arterial blood pressure did not change. There was no significant change in renal blood flow or in renal vascular resistance in response to acute sodium depletion. Fig. 5 shows that after acute sodium depletion there was a significant upward shift in the dose-response curve of $A_{I I}$ but there was no significant change in the renal blood flow response curve of norepinephrine. As shown in Table IA, the mean overall response to $\mathrm{A}_{\text {II }}$ decreased from 87 to $65 \mathrm{ml} / \mathrm{min}(P<0.01)$ after acute sodium depletion, whereas there was no change in the mean response to norepinephrine (46 vs. 42 $\mathrm{ml} / \mathrm{min}$; NS).

Acute sodium repletion. To determine the effect of acute sodium repletion on the renal vascular response to the two hormones, studies were performed in sodium-depleted dogs before and after administration of an infusion of Ringer's lactate solution equal to $5 \%$ of the body weight. As indicated in Table IB, the infusion induced a significant decline in hematocrit and in mean PRA from 39.6 to $21.6 \mathrm{ng} / \mathrm{ml}$ per $\mathrm{h}(P$ $<0.05$ ). Cardiac output increased, total peripheral vascular resistance fell, and mean arterial pressure did not change. Renal blood flow rose but there was no change in renal vascular resistance.

Acute sodium repletion was associated with an enhancement of the renal vascular response to $A_{I I}$ (Table IB); the mean overall response to $A_{I I}$ rose significantly from 38 to $56 \mathrm{ml} / \mathrm{min}(P<0.01)$. There was no change in the renal blood flow response for norepinephrine after acute sodium repletion (Table IB); the mean overall response to norepinephrine after sodium depletion was not significantly different from the control period (48 vs. $45 \mathrm{ml} / \mathrm{min}$; NS).

\section{Effect of the converting enzyme inhibitor on renal vascular reactivity}

To determine the effect of a decrease in $A_{I I}$ without changes in the balance of sodium upon renal vascular reactivity to $A_{11}$ and norepinephrine, the renal blood flow responses to both hormones were measured before and after infusion of the converting enzyme inhibitor, SQ 20,881, in three groups of animals: those with acute sodium depletion (Protocol 1), those with chronic sodium depletion (Protocol 2a) and those pretreated with DOCA and a high salt diet (Protocol 3).

Acute sodium depletion. Table IA indicates the hemodynamic effects that resulted when CEI was administered to the dogs that had been acutely depleted of sodium by furosemide. After CEI administration, there was a significant fall in arterial blood

TABLE I

Effects of Acute Sodium Depletion (A), Acute Chronic Repletion (B), and CEI on Systemic and Renal Hemodynamics, Hematocrit, PRA, and Renal Vascular Response

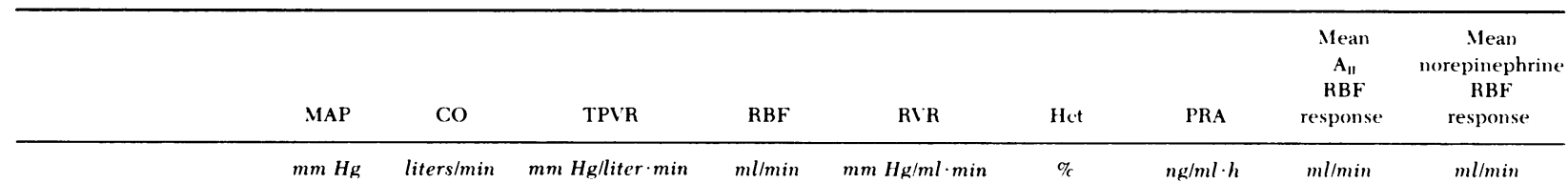

A. Acute sodium depletion

$(n=13)$

1. Control

2. Furosemide

3. CEI

$113 \pm 5$

$3.9 \pm 0.3$

$29.9 \pm 2.4$

$277 \pm 21$

$0.43 \pm 0.04$

$265 \pm 25$

$P(2$ vs. 1$)$

$102 \pm 4$

$3.2 \pm 0.4$

$37.5 \pm 3.4$

$323 \pm 26$

$<0.05$

$P(3$ vs. 2$)$

NS
$<0.001$

$<0.01$

NS

$0.33 \pm 0.03$

$37 \pm 1$

$1.8 \pm 0.3^{*}$

$87 \pm 13$

$46 \pm 8$

$0.33 \pm 0.03$

$45 \pm 1$

$14.4 \pm 4.1$

$65 \pm 13$

$42 \pm 8$

$<0.001$

$<0.005$

$<0.001$

$18.6 \pm 5.2$

$80 \pm 14$

$40 \pm 9$

$\mathrm{NS} \quad \mathrm{NS}<0.0 .5$

$\mathrm{NS}$

$\mathrm{NS}$

B. Acute sodium repletion $(n=6)$

Control

Ringer's infusion

P

$$
\begin{array}{cc}
122 \pm 8 & 2.3 \pm 0.3 \\
117 \pm 6 & 3.6 \pm 0.6 \\
\text { NS } & <0.05
\end{array}
$$
$60.3 \pm 11.5 \quad 209 \pm 19$
$37.8 \pm 8.1 \quad 253 \pm 28$
$<0.01$
$0.60 \pm 0.05$
$0.51 \pm 0.08$
$\mathrm{NS}$

$44 \pm 3$
$35 \pm 2$
$<0.001$
$39.6 \pm 7.2$
$21.6 \pm 5.8$

$<0.0 .5$

$38 \pm 6$
$56 \pm 7$
$<0.01$

$48 \pm 6$

$45 \pm 5$

$\mathrm{NS}$

Values are mean $\pm \mathrm{SE}$. The number of experiments is given in parentheses after each subheading. Hct, hematocrit; CEI, converting enzyme inhibitor; NS, not significantly different. For other abbreviations see Fig. 1.

${ }^{*} n=9$. 


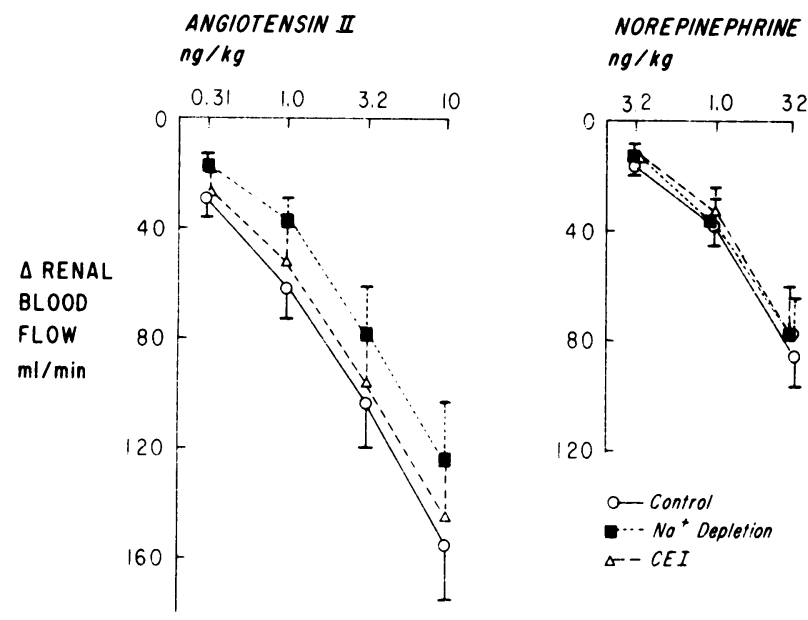

Figure 5 Influence of acute $\mathrm{Na}^{+}$depletion by furosemide and of $\mathrm{CEI}$ on the renal vascular responses to $\mathrm{A}_{I I}$ and norepinephrinc. Vertical lines indicate mean $\pm \mathrm{SE}(n=13)$.

pressure from 112 to $102 \mathrm{~mm} \mathrm{Hg}(P<0.001)$. Total peripheral vascular resistance also fell significantly since there was no change in cardiac output. Renal blood flow increased markedly from 26.5 to $32.3 \mathrm{ml}$ $(P<0.001)$ after CEI and renal vascular resistance declined. PRA rose slightly but not significantly from 14.4 to $18.6 \mathrm{ng} / \mathrm{ml}$ per $\mathrm{h}$ after CEI (NS).

Fig. 5 indicates that after CEI administration to the acutely sodium-depleted dogs, the $\mathrm{A}_{\text {II }}$ dose-response curve was shifted back toward the control curve, while the dose-response curve of norepinephrine was not altered. The mean overall effect of $A_{I I}$ on renal blood flow increased from $6.5 \mathrm{ml} / \mathrm{min}$ during acute sodium depletion to $80 \mathrm{ml} / \mathrm{min}(P<0.05)$ after CEI, a value not significantly different from that obtained in the control period, $87 \mathrm{ml} / \mathrm{min}$ (Table IA). In these dogs, the mean renal vascular response to norepinephrine was not changed b! CEI ( 42 vs. $40 \mathrm{ml} / \mathrm{min}$, Table IA).

Chronic sodium depletion. Table II (Experiment A) shows that the intravenous administration of CEI to dogs with dietary sodium depletion induced a significant fall in mean arterial pressure $(108-99 \mathrm{~mm}$ Hg; $P<0.0 .5)$. In the three dogs in which cardiac ontput was measured, it increased slightly from 3.0 to 3.5 liters $/ \mathrm{min}$ and total vascular resistance declined from 36.6 to $31.7 \mathrm{~mm} \mathrm{Hg}$ /liters per min. Mean renal blood flow increased significantly from 261 to 321 $\mathrm{ml} / \mathrm{min}$ and mean renal vascular resistance declined from 0.45 to $0.34 \mathrm{~mm} \mathrm{Hg} / \mathrm{ml}$ per min. PRA increased from 11.9 to 27.3 after CEI but this change was not significant.

Fig. 6 depicts the effect of CEI on the renal blood flow responses to $A_{I I}$ and norepinephrine in this group of sodium-depleted dogs. The renal vasculature exhibited a marked enhancement of the response to $A_{\text {II }}$ which was apparent at all doses; the mean overall effect increased from 63 to $96 \mathrm{ml} / \mathrm{min}$ (Table IIA). In contrast, the dose-response curve to norepinephrine was uninfluenced by CEI (Fig. 6); and mean overall response averaged $6(0 \mathrm{ml} / \mathrm{min}$ before and $6.3 \mathrm{ml} / \mathrm{min}$ (NS) after CEI (Table IIA).

TABILE II

Effects of CEI on Systemic and Renal Hemodynamics, Hematocrit, PRA, and Re'nal Vascular Response in Chronic $\mathrm{Na}^{+}$Depletion (A) and Chronic Na Excess (B)

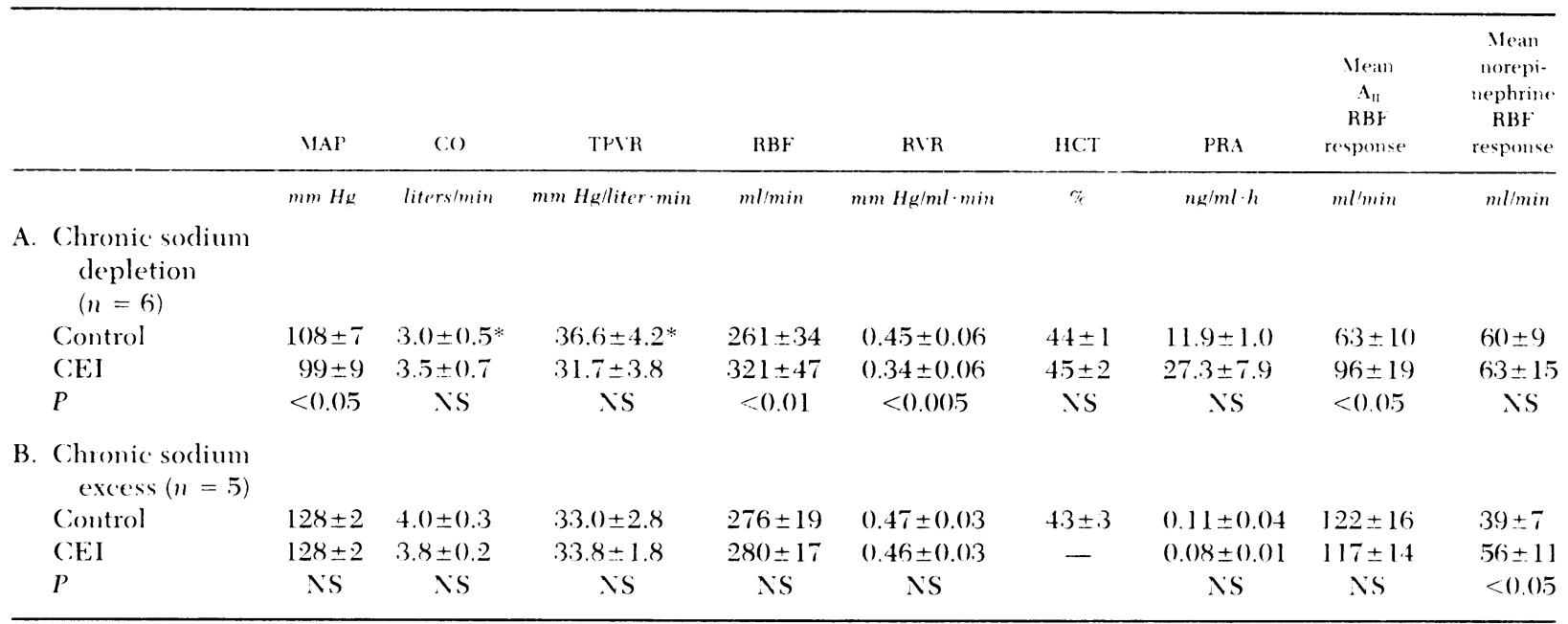

Values are mean \pm SE. The number of experiments is given in parentheses after each subheading. For abbreviations sef Fig. 1 and Table 1 .

$* n=3$. 


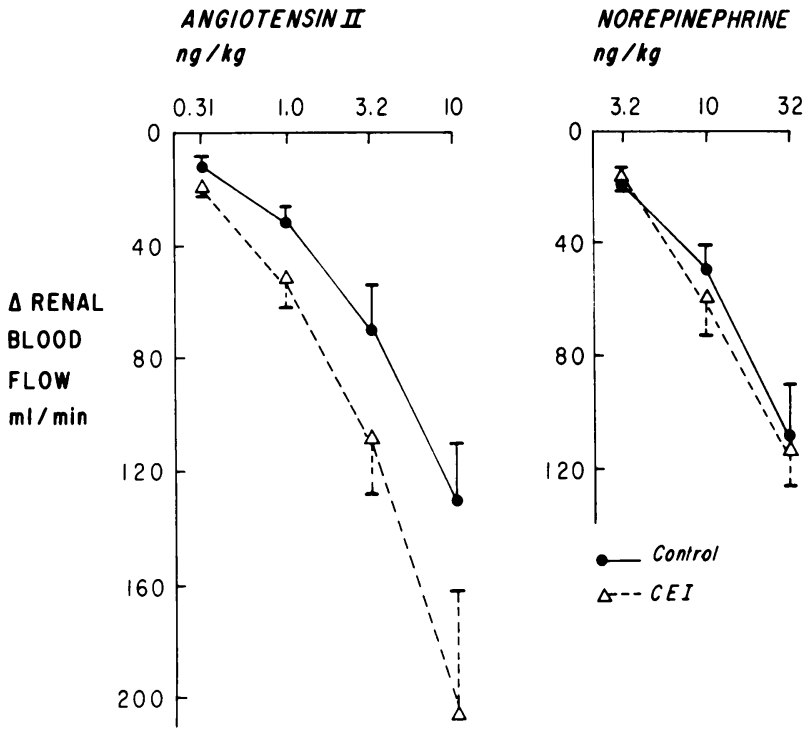

FIGURE 6 Influence of CEI on the renal vascular response to $A_{I I}$ and norepinephrine. Vertical lines indicate mean $\pm S E$. $(n=6)$.

Chronic sodium excess. Table IIB indicates that the administration of CEI to dogs given a high salt diet and DOCA had no significant effects on systemic or renal hemodynamics or on the suppressed level of PRA. Similarly, the $A_{\text {II }}$ dose-response curve was unaffected by converting enzyme blockade in these animals; the mean overall response to $A_{I I}$ was $122 \mathrm{ml} / \mathrm{min}$ before and $117 \mathrm{ml} / \mathrm{min}$ after CEI (differences NS, Table IIB). However, administration of
CEI was associated with an enhanced renal blood flow response to norepinephrine; the mean overall response increased from 39 to $56 \mathrm{ml} / \mathrm{min}(P<0.05$, Table IIB).

Bradykinin infusion. In vitro and in vivo studies have indicated that the enzyme which converts $A_{I}$ to $A_{I I}$ is also a kininase (31) and that the administration of CEI may increase urinary and circulating kinin concentrations (26). To exclude the possibility that the enhanced renal vascular responses to $A_{I I}$ observed after CEI resulted from an increase in circulating bradykinin, the renal vascular responses to $A_{l I}$ and norepinephrine were examined in six sodiumdeprived dogs before and during an infusion of bradykinin.

Table IIIA indicates that the bradykinin infusions induced an average fall in mean arterial blood pressure from 122 to $96 \mathrm{~mm} \mathrm{Hg}(P<0.005)$. Total peripheral vascular resistance fell significantly during bradykinin infusion and cardiac output did not change. Renal blood flow increased sharply from 209 to 278 $\mathrm{ml} / \mathrm{min}(P<0.005)$ and renal vascular resistance fell. These changes are comparable to those induced by administration of CEI to sodium-depleted dogs. The upper panel of Fig. 7 shows, however, that the doseresponse curves for $A_{I I}$ and norepinephrine were not changed from control values during the bradykinin infusions. The mean overall $\mathrm{A}_{\mathrm{II}}$ effect was $38 \mathrm{ml} / \mathrm{min}$ during the control period and $31 \mathrm{ml} / \mathrm{min}$ during the bradykinin infusions (difference NS, Table IIIA). The respective norepinephrine responses were 48 and $43 \mathrm{ml} / \mathrm{min}$ (difference NS, Table IIIA).

TABLE III

Effects of Bradykinin (A) and Indomethacin (B) on Systemic and Renal Hemodynamics, Hematocrit, PRA, and Renal Vascular Response

\begin{tabular}{|c|c|c|c|c|c|c|c|c|}
\hline MAP & $\mathrm{CO}$ & TPVR & RBF & RVR & HCT & PRA & $\begin{array}{c}\text { Mean } \\
\mathbf{A}_{\mathrm{II}} \\
\mathrm{RBF} \\
\text { response }\end{array}$ & $\begin{array}{c}\text { Mean } \\
\text { norepinephrin } \\
\text { RBF } \\
\text { response }\end{array}$ \\
\hline$m m \mathrm{Hg}$ & liters/mil & $m m \mathrm{Hg} /$ liter $\cdot \min$ & $\mathrm{ml} / \mathrm{min}$ & $\mathrm{mm} \mathrm{Hg} / \mathrm{ml} \cdot \min$ & $\%$ & $n g / m l \cdot h$ & $\mathrm{ml} / \mathrm{min}$ & $\mathrm{ml} / \mathrm{min}$ \\
\hline
\end{tabular}

A. Effect of brady$\operatorname{kinin}(n=6)$

$\begin{array}{lccccccccc}\text { Control } & 122 \pm 8 & 2.3 \pm 0.3 & 60.3 \pm 11.5 & 209 \pm 19 & 0.60 \pm 0.05 & 44 \pm 3 & 39.6 \pm 7.2 & 38 \pm 6 & 48 \pm 6 \\ \text { Bradykinin } & 96 \pm 6 & 2.6 \pm 0.4 & 41.0 \pm 6.5 & 278 \pm 27 & 0.36 \pm 0.04 & 46 \pm 3 & 48.7 \pm 11.9 & 31 \pm 5 & 43 \pm 9 \\ P & <0.005 & \text { NS } & <0.05 & <0.005 & <0.005 & \text { NS } & \text { NS } & \text { NS } & \text { NS }\end{array}$

B. Effect of indomethacin $(n=7)$

Control Indomethacin P

$149 \pm 13$
$133 \pm 12$

$<0.001$

$0.93 \pm 0.09$
$1.05 \pm 0.10$
$\quad<0.0 .5$

$\begin{array}{cccc}37 \pm 2 & 10.7 \pm 1.6 & 49 \pm 11 & 42 \pm 9 \\ - & 7.7 \pm 1.1 & 40 \pm 8 & 33 \pm 6 \\ & <0.05 & \text { NS } & \text { NS }\end{array}$

Values are mean $\pm \mathrm{SE}$. The number of experiments is given in parentheses after each subheading. For abbreviations see Fig. 1 and Table I. 


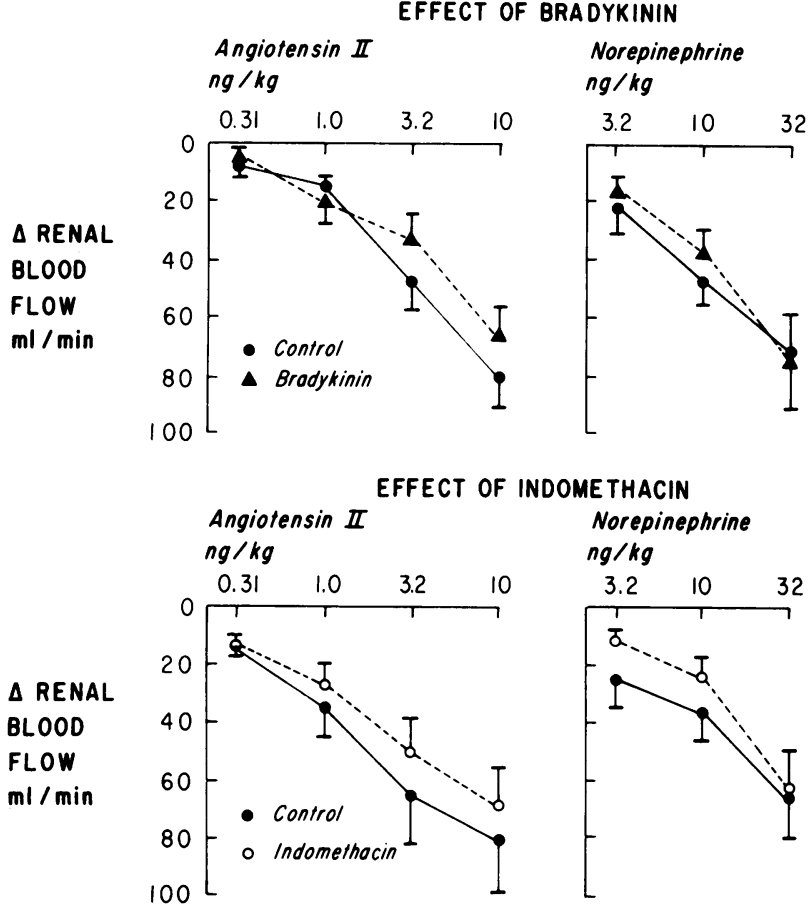

FIGURE 7 Influence of bradykinin and of indomethacin on the renal vascular response. Vertical lines indicate mean $\pm \mathrm{SE}$. Bradykinin, $n=6$; Indomethacin, $n=7$.

\section{Effect of indomethacin on renal vascular reactivity}

To assess a possible role of the prostaglandins in determining the vascular response to $A_{I I}$ and(or) norepinephrine, the responses to the two hormones were measured in sodium-deprived dogs before and after administration of the cyclo-oxygenase inhibitor, indomethacin (28). Table IIIB indicates that the administration of indomethacin resulted in no significant changes in mean arterial blood pressure, cardiac output, or total peripheral vascular resistance. Renal blood flow declined significantly after indomethacin, from 149 to $133 \mathrm{ml} / \mathrm{min}(P<0.001)$, and there was an increase in renal vascular resistance. PRA declined slightly but significantly after indomethacin. The lower panel of Fig. 7 indicates that the doseresponse curves to $A_{I I}$ and to norepinephrine were not significantly changed after the administration of indomethacin. The mean overall blood flow response to $A_{\text {II }}$ was $49 \mathrm{ml} / \mathrm{min}$ before and $40 \mathrm{ml} / \mathrm{min}$ after the cyclo-oxygenase inhibitor had been infused (difference NS, Table IIIB). The corresponding values for norepinephrine were 42 and $33 \mathrm{ml} / \mathrm{min}$ (NS).

\section{DISCUSSION}

When the renin-angiotensin system is activated by sodium depletion, there is an increase in the con- centration of circulating $A_{I I}(1)$ but there is no hypertension. Recent studies with inhibitors of $A_{I I}$ generation or antagonist analogues have provided evidence that the increase in $A_{I I}$ during sodium depletion contributes significantly to the maintenance of arterial pressure $(2-5)$. Paradoxically, during sodium deprivation, the pressor responsiveness to infusions of $A_{I I}$ is diminished (6-9). Conversely, in normal or positive sodium balance, $\mathrm{A}_{\mathrm{II}}$ contributes little to the maintenance of arterial pressure and there is an enhanced blood pressure responsiveness to exogenous $A_{I I}(2$, 7-9). Decreases in the pressor response to $A_{I I}$ have also been documented in a variety of diseases in which the renin-angiotensin system is activated $(7,9,13-17)$.

The influence of sodium balance on the vascular action of $A_{I I}$ has been studied primarily by monitoring the blood pressure rise produced by an intravenous infusion of the hormone $(6-9,13-17)$. This approach, however, is complicated by the fact that $A_{l l}$, in addition to its direct action to produce vasoconstriction of arteriolar smooth muscle, also influences blood pressure indirectly through actions on the central and sympathetic nervous systems $(32,33)$, on the adrenal medulla (33), the heart (34), and possibly also on the systemic veins (4). In the present studies the responses of the renal circulation to graded subpressor doses of AII and norepinephrine were measured. In this manner, systemic circulatory alterations were avoided and changes in renal blood flow could be used to assess the vasoconstrictor action of the two hormones.

The data indicate that the renal blood flow response to $A_{I I}$ was significantly and selectively depressed by chronic or acute sodium deprivation whereas it was increased by acute repletion of sodium and by chronic sodium excess induced by a high salt intake and DOCA. When examined across groups, the renal vascular response to $A_{I I}$ was inversely related to PRA. These observations confirm and extend those made by Hollenberg et al. in salt-deprived humans with the ${ }^{133}$ xenon washout technique $(10,12)$. Moreover, the changes in the renal vascular response to $A_{I I}$ reported here are directionally similar to the changes in its pressor effect that have been reported in rats (8), dogs (6), and humans $(7,9,13)$ during variations of the balance of sodium.

The data also indicate that there were no significant changes in the renal vascular response to norepinephrine during chronic or acute changes of sodium balance. These observations conflict with previous studies by Kilcoyne and Cannon in dogs (35) and by Hollenberg et al. in humans (10) which suggested that sodium deprivation increases the renal vascular response to norepinephrine. Since the changes reported previously were slight and since these workers used the ${ }^{133}$ xenon technique to measure renal blood 
flow, differences in methodology may account for the different results. In the present studies, renal vascular reactivity to norepinephrine appeared not to be dependent upon the activity of the renin-angiotensin system because no relationship between the PRA and renal vascular response to norepinephrine was found.

The administration of CEI to sodium-depleted animals with increased PRA induced a fall in arterial blood pressure, total peripheral vascular and renal vascular resistances, and an increase in renal blood flow. In contrast, there was no significant change in these parameters in the high salt-DOCA animals in which the renin-angiotensin system was suppressed. These data confirm previous results in the rat (4), rabbit (3), dog (2), and humans (5) and illustrate the important role of the renin-angiotensin system in the maintenance of arterial blood pressure during sodium depletion. They also show, in agreement with previous studies $(3,36)$, that $A_{\text {II }}$ participates in the regulation of the renal vascular tone during sodium depletion.

The renal vascular response to $A_{I I}$ increased significantly after inhibition of converting enzyme in dogs with acute or chronic sodium depletion that had increased PRA. In contrast, in animals with suppressed PRA (salt-DOCA), the vascular response to $A_{I I}$ was unchanged by CEI. The effect of CEI upon the renal vascular response was specific for $A_{\text {II }}$ since during sodium depletion, the norepinephrine response was unaffected by converting enzyme inhibition. The surprising enhancement of the norepinephrine response after CEI in the salt-DOCA dogs is unexplained but possibly may relate to differences in catecholamine storage and re-uptake in the tissues (37).

Several lines of evidence suggest that the renal vascular response to $A_{I I}$ was increased after administration of CEI because inhibition of converting enzyme reduced the amount of endogenous $A_{I I}$ available to react with the vascular $A_{I I}$ receptors. First, a variety of in vitro (38) and in vivo (39) evidence indicates that CEI results in significant decreases in the conversion of $A_{I}$ to $A_{I I}$. Indeed, in the present experiments, the arterial pressure rise induced by intravenous $A_{I}$ was decreased by more than one-half after the administration of $0.25 \mathrm{mg} / \mathrm{kg}$ of CEI (see Methods). Second, CEI lowered mean arterial blood pressure and increased the renal blood flow in sodium depletion, a situation in which the vasoconstrictor action of $A_{I I}$ is known to be involved in the maintenance of arterial pressure $(2,3)$. Finally, acute sodium repletion with Ringer's lactate which decreased the PRA induced, like CEI, an enhancement of the renal vascular response to $\mathrm{A}_{\mathrm{II}}$.

Two alternative explanations for the effect of CEI upon the vascular response to $A_{I I}$ were considered. The first was that the increase in the $A_{I I}$ response might be a nonspecific effect of the renal vasodilation induced by CEI. However, an analysis of covariance between the $A_{\text {II }}$ effect and the base-line renal blood flow values failed to reveal a significant relationship between these variables. In addition, a dissociation between changes in renal blood flow and the renal vascular response to $A_{I I}$ was evidenced during bradykinin infusion (increase in blood flow and no change in the $A_{11}$ response) and after diuresis with furosemide (no change in blood flow and decrease in the response). The second explanation was invoked because the enzyme that converts $A_{I}$ to $A_{I I}$ is also a kinindestroying enzyme (kininase II) (31) and because a recent report has shown that infusion of CEI enhanced the survival of endogenous kinins (26). In the present experiments, bradykinin infusions produced systemic and renal hemodynamic changes comparable to CEI, yet had no influence on the renal blood flow response to $A_{\text {II }}$. It is thus unlikely that the enhanced vascular response to $A_{I I}$ after CEI was due to an increase in the concentration of endogenous kinins. Furthermore, CEI did not affect arterial blood pressure or renal blood flow in the renin-suppressed dogs (salt-DOCA), suggesting that at the dose utilized, its effects were due solely to blockade of $A_{I I}$ generation. This interpretation is in agreement with observations of Miller et al. (40) who administered a similar dose of CEI to conscious dogs on a normal sodium diet and found no alterations in the concentrations of plasma bradykinin measured by radioimmunoassay.

As outlined in the Introduction, four major mechanisms have been postulated to explain the inverse relationship between the balance of sodium and the vascular effect of $A_{I I}$. They are: $(a)$ that sodium alters the contractile response of the vascular smooth muscle to the action of $A_{\mathrm{II}}$, (b) that the vasopressor effect of exogenous $A_{I I}$ is depressed or enhanced as a consequence of whether more or less vascular receptors for $A_{I I}$ are occupied by the endogenously produced polypeptide, $(c)$ that the number of $A_{I I}$ vascular receptors may vary, and that the pressor effect of $A_{I I}$ is a direct function of this number, and $(d)$ that the net pressor effect of $A_{I I}$ is the sum of its vasoconstrictor action and of opposing vasodilator influences such as the prostaglandins.

The inverse relationship between the renal vascular effect of $A_{I I}$ and the balance of sodium found in the present studies is consistent with the first hypothesis, initially proposed by Ames et al. (9) and Brunner et al. (18), that the vasoconstrictor action of $A_{I I}$ is directly influenced by sodium. In the study of Brunner et al. (18) the amount of $A_{\text {II }}$ antibody (infused intravenously) required to block the pressor response to a given dose of $A_{I I}$ was used to assess vascular reactivity to the octapeptide. This amount was diminished in sodium-deprived rats and was increased in rats fed a high salt diet. It was postulated that the changes in 
antibody requirement (i.e., the index of vascular reactivity) were independent of the endogenous $A_{I I}$ level since nephrectomized rats (with undetectable plasma $A_{\text {II }}$ ) required less antibody to block the pressor effect of $A_{I I}$ if they had been sodium-restricted than if they were maintained on a normal sodium intake (18). Additional evidence suggesting a direct effect of sodium upon the contractile response to $\mathrm{A}_{\mathrm{II}}$ was provided by Strewler et al. who demonstrated in vitro that aortic vascular strips from sodium-restricted rabbits were less responsive to $A_{I I}$ than strips from rabbits fed a high salt diet (11). However, strong evidence against the sodium hypothesis in the present studies are the observations in the dogs with acute and chronic sodium depletion, that the renal vascular response to $A_{I I}$ was enhanced immediately after the administration of CEI and before a change in sodium balance could take place.

Three observations in the present study are compatible with the second hypothesis that the renal vascular response to $A_{I I}$ is blunted when the vascular receptors for $A_{I I}$ are occupied by endogenously formed polypeptide and enhanced when endogenous $A_{\text {II }}$ availability is reduced. These are: $(a)$ there was an inverse relationship between PRA (and presumably, endogenous $A_{I I}[1]$ ), and renal vascular reactivity to $A_{I I}$ in dogs maintained on different sodium diets, $(b)$ acute natriuresis blunted the renal $A_{\text {II }}$ response while increasing PRA, and acute sodium repletion enhanced the renal $A_{I I}$ response while suppressing plasma renin, and $(c)$ there was a marked enhancement of the renal $A_{\text {II }}$ response in dogs with acute and chronic sodium depletion after administration of a compound ( $S Q$ 20,881 ) which inhibited conversion of $A_{I}$ to $A_{I I}$, whereas the same compound did not influence renal vascular reactivity to $A_{I I}$ in animals with suppressed PRA.

In the aggregate therefore, the results of the present study are consistent with the hypothesis that the vascular response to $A_{I I}$ is dependent, at least partially, upon the competition between endogenous and exogenous hormone for the same receptor sites. When the renal vascular $A_{\text {II }}$ receptors are occupied by large amounts of endogenous $A_{I I}$ the renal vasoconstriction produced by exogenous $A_{I I}$ is diminished. Conversely, when the amount of endogenous $A_{I I}$ at the renal vascular receptor sites is low, exogenous $A_{\text {II }}$ produces a greater degree of vasoconstriction. The results of the present study are consistent with findings of Thurston and Laragh in their study of the pressor response to $A_{I I}$ in the rat (19). These investigators reported that the blunted pressor response to $A_{I I}$ in salt-deprived rats could be enhanced by inhibiting conversion of $A_{1}$ to $A_{I I}$ with $S Q 20,881$.

A third hypothesis to explain the influence of sodium balance upon the vasoconstrictor effect of $A_{I I}$ has recently been proposed by Devynck and Meyer
(20). These workers have shown that the number of $A_{\text {II }}$ receptors on uterine smooth muscle increased significantly several hours after bilateral nephrectomy, a maneuver which abruptly diminishes circulating $A_{\text {II }}$ (41). Based on these findings, they postulated that the number of vascular $A_{\text {II }}$ receptors might decline when the concentration of $A_{I I}$ is high and increase when its concentration is low. The number of vascular receptors would determine, in turn, the response of vascular smooth muscle to $A_{\mathrm{II}}$. This concept is in accord with a number of studies that indicate that several hormones (42-45) regulate the number of receptors in their target organs. For example, in vitro and in vivo studies have shown that the insulin concentration is inversely related to the concentration of receptors in its target tissue, i.e., increase of insulin reduces the tissue receptor concentration and vice versa (42, 43). Whether circulating $A_{I I}$ regulates the number of its vascular receptors is unknown. The present data cannot exclude the possibility that the number of $A_{I I}$ receptors in the renal vasculature may be influenced by the concentration of $A_{I I}$. The data suggest, however, that such a mechanism is insufficient to account for the changes in renal vascular responsiveness to $A_{I I}$ that were observed. In studies of other hormones, alterations in receptor density in the target tissues were observed only after chronic changes in hormone concentration (42-45). Similarly, the increase in the number of uterine $A_{I I}$ receptors after nephrectomy took place over more than $15 \mathrm{~h}(41)$. In contrast, the enhancement of the $A_{11}$ renal vascular response after acute sodium repletion and after CEI and its blunting after acute natriuresis and diuresis in the present study occurred within less than $1 \mathrm{~h}$, a duration too brief to anticipate large changes in the number of receptors.

An additional observation supports the concept that the variations in the renal vascular sensitivity to $A_{I I}$ observed in the present study are not likely to be due to changes in the number of $A_{I I}$ vascular receptors. Ames et al. noted that the pressor sensitivity to $A_{I I}$ increased during chronic infusions of $A_{\mathrm{II}}(9)$. If a high circulating concentration of $A_{I I}$ resulted in a decrease in the number of its vascular receptors, one would have expected the experimental subjects to develop a diminished pressor sensitivity. Since the subjects of Ames et al. (9) developed significant sodium retention during the $A_{I I}$ infusions, it is likely that there was suppression of endogenous renin secretion (and endogenous $A_{\text {III }}$, making more vascular receptors available to interact with the infused polypeptide.

The fourth hypothesis proposed to explain variations in vascular reactivity to angiotensin II is based upon the assumption that vasodilator forces modulate the vascular effects of this polypeptide. McGiff et al. (21) and others (46) have shown that $A_{11}$ and norepinephrine (21) induce biosynthesis of prostaglandins 
of the $\mathrm{E}$ series in the kidney. When infused into the renal artery, the initial vasoconstriction induced by $\mathrm{A}_{\text {II }}$ was followed, 2-5 min later, by a partial recovery of the renal blood flow which was accompanied by increased levels of prostaglandin E-like substances in renal venous blood (21). Both later events were prevented by blockage of prostaglandin synthesis by administration of cyclo-oxygenase inhibitors (21). Subsequently Aiken and Vane reported that the degree of renal vasoconstriction induced by an infusion of $A_{\text {II }}$ was enhanced by administration of indomethacin or meclofenamate (29). In addition, other data suggest that changes in the synthesis and release of vascular and renal prostaglandins may be influenced by the renin-angiotensin system $(47,48)$. Accordingly, the possibility might be entertained that the blunting of the renovascular action of $A_{I I}$ during negative sodium balance is due to synthesis and release of prostaglandins (or other vasodilator substances) perhaps stimulated by the increased circulating or tissue concentrations of $A_{\text {II }}$ (48).

Although this hypothesis is attractive it does not appear to provide an explanation for the alterations in the renal vascular reactivity to $A_{I I}$ observed in the present experiments for two reasons. First, the modulating effect of prostaglandins of the E series on vasoconstrictor stimuli is relatively nonspecific, i.e., prostaglandins attenuate the vasoconstriction produced by $\mathrm{A}_{\mathrm{Il}}$, norepinephrine, renal nerve stimulation, and ischemia (21). In the present study, however, the blunting of the renal vascular responsiveness to $A_{\text {II }}$ after acute diuresis and by dietary sodium deprivation and its enhancement by sodium repletion and by the high salt diet and DOCA were selective for $A_{\mathrm{II}}$. If such changes in sensitivity were prostaglandinmediated, similar responses would have been expected for norepinephrine.

Second, in the present experiments the administration of indomethacin in doses equal to those which have been shown to inhibit renal prostaglandin biosynthesis (29) failed to enhance the renal vascular response to $\mathrm{A}_{\mathrm{II}}$. Although measurements of prostaglandin excretion were not performed, the fact that the drug reduced basal renal blood flow and PRA provides evidence for inhibition of prostaglandin production by the kidneys $(29,49)$. The failure of indomethacin to enhance the renal vascular response to $A_{I I}$ and norepinephrine might appear to be at variance with observations of Aiken and Vane who reported that indomethacin enhanced the renal blood flow response to these hormones (29). However, in the experiments of Aiken and Vane, $A_{I I}$ and norepinephrine were infused into the renal artery for 5-6 min, a duration of time adequate to induce prostaglandin synthesis in response to the vasoconstrictor action of the two hormones (21). On the other hand, in the present experiment, $A_{I I}$ and norepinephrine were in- jected as bolus injections and the maximal reduction of renal blood flow (which almost always occurred within 5-10 s) was used as the indicator of the renal vascular response. From the data of McGiff et al. (21) it appears that this initial response probably antedated significant prostaglandin synthesis and may more properly be a reflection of the vasoconstriction by $A_{I I}$ or norepinephrine. Recently, Nishikawa et al. (50) also reported that the acute vasoconstrictor responses to $A_{I I}$ in an isolated kidney preparation were not enhanced by pretreatment with inhibitors of prostaglandin synthesis.

In summary, the present studies demonstrate that the renal vascular reactivity to $A_{\text {II }}$ was blunted by acute or chronic sodium depletion (which stimulates renin secretion) and was enhanced by acute sodium repletion or chronic administration of a high salt diet and DOCA (which suppress renin secretion) or by CEI (which presumably reduced the concentration of circulating $\mathrm{A}_{\mathrm{II}}$ ). The renal vascular reactivity to norepinephrine was not significantly influenced by alteration of sodium balance or by administration of converting enzyme (except for an enhancement of norepinephrine sensitivity which occurred after CEI in dogs pretreated with DOCA and salt). The data are consistent with the hypothesis that variations in the degree of renal vascular effect produced by exogenous $A_{I I}$ is determined by the number of vascular receptor sites unoccupied by endogenous $A_{\mathrm{II}}$. They did not suggest that direct effects of sodium on the contractile machinery, alterations in the number of receptor sites, or activity of the prostaglandins were involved.

A similar competition between endogenous and exogenous $A_{\text {II }}$ for the same vascular receptors may explain the variations in renal vascular reactivities to $A_{I I}$ in situations where the renin-angiotensin II system has been activated by disease. Subnormal renal blood flow responses have been reported during intravenous administration of $A_{I I}$ to patients with cirrhosis and ascites (13), patients with severe hypertension (51), and during intrarenal administration of $A_{I I}$ to normal women receiving estrogen-containing oral contraceptives (52). Similarly, it may explain the blunted pressor sensitivity to $A_{I I}$ in a variety of diseases $(7,9,14-17)$. For example, the blunted pressor response to $A_{I I}$ observed in patients with the syndrome of juxtaglomerular cell hyperplasia (Bartter's syndrome) is significantly enhanced when peripheral plasma renin activity is suppressed by saline infusion (53) or administration of propranolol or indomethacin (16).

\section{ACKNOWLEDGMENTS}

We are grateful to Robert $\mathbf{R}$. Sciacca for invaluable assistance with the statistical analysis and for constructive comments and to Dr. H. Gavras for the plasma renin activity determinations. Ms. Deborah Fowler and Ms. Barbara 
Moore provided expert technical help. Ms. Carole Michel provided excellent secretarial help. The converting enzyme inhibitor (SQ 20,881) was kindly provided by Dr. R. Vukovich, Squibb Institute, Princeton, N. J. Indomethacin was a gift of Merck Sharp \& Dohme Research Lab, West Point, Pa.

This work was supported by grant HL 10182 from the U. S. Public Health Service.

\section{REFERENCES}

1. Gocke, D. J., J. Gerten, L. M. Sherwood, and J. H. Laragh. 1969. Physiological and pathological variations of plasma angiotensin II in man. Circ. Res. 24, 25(Suppl. I): $131-146$

2. Johnson, J. A., and J. O. Davis. 1973. Effects of a specific competitive antagonist of angiotensin II on arterial pressure and adrenal steroid secretion in dogs. Circ. Res. 32, 33(Suppl. I): 159-168.

3. Mimran, A., L. Guiod, and N. K. Hollenberg. 1974. The role of angiotensin in the cardiovascular and renal response to salt restriction. Kidney Int. 5: 348-355.

4. Coleman, T. G., A. W. Cowley, Jr., and A. C. Guyton. 1975. Angiotensin and the hemodynamics of chronic salt deprivation. Am. J. Physiol. 229: 167-171.

5. Sancho, J., R. Re, J. Burton, A. C. Barger, and E. Haber. 1976. The role of the renin-angiotensin-aldosterone system in cardiovascular homeostasis in normal human subjects. Circulation. 53: 400-405.

6. Davis, J. O., P. M. Hartroft, E. O. Titus, C. C. J. Carpenter, C. R. Ayers, and H. E. Spiegel. 1962. The role of the renin-angiotensin system in the control of aldosterone secretion. J. Clin. Invest. 41: 378-389.

7. Kaplan, N. M., and J. G. Silah. 1964. The effect of angiotensin II on the blood pressure in humans with hypertensive disease. J. Clin. Invest. 43: 659-669.

8. Reid, W. D., and J. H. Laragh. 1965. Sodium and potassium intake, blood pressure and pressor response to angiotensin. Proc. Soc. Exp. Biol. Med. 120: 26-29.

9. Ames, R. P., A. J. Borkowski, A. M. Sicinski, and J. H. Laragh. 1965. Prolonged infusions of angiotensin II and norepinephrine and blood pressure, electrolyte balance, and aldosterone and cortisol secretion in normal man and in cirrhosis with ascites. J. Clin. Invest. 44: $1171-1186$.

10. Hollenberg, N. K., H. S. Solomon, D. F. Adams, H. L. Abrams, and J. P. Merrill. 1972. Renal vascular responses to angiotensin and norepinephrine in normal man. Circ. Res. 31: 750-757.

11. Strewler, G. J., K. J. Hinrichs, L. R. Guiod, and N. K. Hollenberg. 1972. Sodium intake and vascular smooth muscle responsiveness to norepinephrine and angiotensin in the rabbit. Circ. Res. 31: 758-766.

12. Hollenberg, N. K., W. R. Chenitz, D. Adams, and G. M. Williams. 1974. Reciprocal influence of salt intake on adrenal glomerulosa and renal vascular responses to angiotensin II in normal man. J. Clin. Invest. 54: $34-42$.

13. Laragh, J. H., P. J. Cammon, C. J. Bentzel, A. M. Sicinski, and J. I. Meltzer. 1963. Angiotensin II, norepinephrine and renal transport of electrolytes and water in normal man and in cirrhosis with ascites. J. Clin. Invest. 42: 1179-1192.

14. Johnston, C. I., and A. D. Jose. 1963. Reduced vascular response to angiotensin II in secondary hyperaldosteronism. J. Clin. Invest. 42: 1411-1420.

15. Bartter, F. C., P. Pronove, J. R. Gill, Jr., and R. C. MacCardle. 1962. Hyperplasia of the juxtaglomerular complex with hyperaldosteronism and hypokalemic alkalosis. A new syndrome. Am. J. Med. 33: 811-828.

16. Fichman, M. P., N. Telfer, P. Zia, P. Speckart, M. Golub, and R. Rude. 1976. Role of prostaglandins in the pathogenesis of Bartter Syndrome. Am. J. Med. 60: 785-797.

17. Küchel, O., K. Horký, M. Pazourek, and I. Gregorová. 1964. Pressor hyporeactivity to angiotensin in Addison's disease. Lancet. II: 1316-1317.

18. Brunner, H. R., P. Chang, R. Wallach, J. E. Sealey, and J. H. Laragh. 1972. Angiotensin II vascular receptors: their avidity in relationship to sodium balance, the autonomic nervous system, and hypertension. J. Clin. Invest. 51: 58-67.

19. Thurston, H., and J. H. Laragh. 1975. Prior receptor occupancy as a determinant of the pressor activity of infused angiotensin II in the rat. Circ. Res. 36: 113-117.

20. Devynck, M. A., and P. Meyer. 1976. Angiotensin receptors in vascular tissue. Am. J. Med. 61: 758-767.

21. McGiff, J. C., K. U. Malik, and N. A. Terragano. 1976. Prostaglandins as determinants of vascular reactivity. Fed. Proc. 35: 2382-2387.

22. Bailie, M. D., F. C. Rector, Jr., and D. W. Seldin. 1971. Angiotensin II in arterial and renal venous plasma and renal lymph in the dog. J. Clin. Invest. 50: 119-126.

23. Ondetti, M. A., N. J. Williams, E. F. Sabo, J. Pluščec, E. R. Weaver, and O. Kocy. 1971. Angiotensin-converting enzyme inhibitors from the venom of Bothrops jararaca. Isolation, elucidation of structure and synthesis. Biochemistry. 10: 4033-4039.

24. Sealey, J. E., J. Gerten-Banes, and J. H. Laragh. 1972. The renin system: variations in man measured by radioimmunoassay or bioassay. Kidney Int. 1: 240-253.

25. Herd, J. A., and A. C. Barger. 1964. Simplified technique for chronic catheterization of blood vessels. J. Appl. Physiol. 19: 791-792.

26. Nasjletti, A., J. Colina-Chourio, and J. McGiff. 1975. Disappearance of bradykinin in the renal circulation of dogs. Effects of kininase inhibition. Circ. Res. 37: $59-65$.

27. McCarthy, D. A., D. E. Potter, and E. D. Nicolaides. 1965. An in vivo estimation of the potencies and half-lives of synthetic bradykinin and kallidin. J. Pharmacol. Exp. Ther. 148: $117-122$.

28. Hamberg, M., and B. Samuelsson. 1974. Prostaglandin endoperoxides. Novel transformations of arachidonic acid in human platelets. Proc. Natl. Acad. Sci. U. S. A. 71: $3400-3404$.

29. Aiken, J. W., and J. R. Vane. 1973. Intrarenal prostaglandin release attenuates the renal vasoconstrictor activity of angiotensin. J. Pharmacol. Exp. Ther. 184: $678-687$.

30. Winer, B. J. 1971. Statistical Principles in Experimental Design. McGraw-Hill Book Company, New York. 2nd edition. 4-36; 261-308; 752-812.

31. Yang, H. Y. T., E. G. Erdös, and Y. Levin. 1971. Characterization of a dipeptide hydrolase (kininase II: angiotensin I converting enzyme). J. Pharmacol. Exp. Ther. 177: 291-300

32. Severs, W. B., and A. E. Daniels-Severs. 1973. Effects of angiotensin on the central nervous system. Pharmacol. Rev. 25: 415-449.

33. Reit, E. 1972. Actions of angiotensin on the adrenal medulla and autonomic ganglia. Fed. Proc. 31: 13381343.

34. Drimal, J., and D. Boska. 1973. Effects of angiotensin 
II on myocardial mechanisms and contractile state of heart muscle. Eur. J. Pharmacol. 21: 130-138.

35. Kilcoyne, M. M., and P. J. Cannon. 1971. Neural and humoral influences on intrarenal blood flow distribution during thoracic caval occlusion. Am. J. Physiol. 220: $1231-1237$.

36. Freeman, R. H., J. O. Davis, S. J. Vitale, and J. A. Johnson. 1973. Intrarenal role of angiotensin II. Homeostatic regulation of renal blood flow in the dog. Circ. Res. 32: 692-698.

37. deChamplain, J., L. R. Krakoff, and J. Axelrod. 1968. Relationship between sodium intake and norepinephrine storage during the development of experimental hypertension. Circ. Res. 23: 479-491.

38. Igic, R., E. G. Erdös, H. S. J. Yeh, K. Sorrells, and T. Nahajima. 1972. Angiotensin I converting enzyme of the lung. Circ. Res. 30, 31(Suppl. II): 51-61.

39. Greene, L. J., A. C. M. Camarogo, E. M. Krieger, J. M. Stewart, and S. H. Ferreira. 1972. Inhibition of the conversion of angiotensin I to II and potentiation of bradykinin by small peptides present in Bothrops jararaca venom. Circ. Res. 30, 31(Suppl. II): 62-71.

40. Miller, E. D., Jr., A. I. Samuels, E. Haber, and A. C. Barger. 1975. Inhibition of angiotensin conversion and prevention of renal hypertension. Am. J. Physiol. 228: $448-453$.

41. Devynck, M. A., B. Rouzaire-Dubois, E. Chevillotee, and P. Meyer. 1976. Variations in the number of uterine angiotensin receptors following changes in plasma angiotensin levels. Eur. J. Pharmacol. 40: 27-37.

42. Gavin, J. R., J. Roth, D. M. Neville, Jr., P. De Meyts, and D. N. Buell. 1974. Insulin-dependent regulation of insulin receptor concentrations: a direct demonstration in cell culture. Proc. Natl. Acad. Sci. U. S. A. 71: $84-88$.

43. Soll, A. H., C. R. Kahn, D. M. Neville, Jr., and J. Roth. 1975. Insulin receptor deficiency in genetic and acquired obesity. J. Clin. Invest. 56: 769-780.
44. Lesniak, M. A., and J. Roth. 1976. Regulation of receptor concentration by homologous hormone. Effect of human growth hormone on its receptor in IM-9 lymphocytes. J. Biol. Chem. 251: 3720-3729.

45. Milgrom, E., L. Thi, M. Atger, and E. E. Baulieu. 1973. Mechanisms regulating the concentration and the conformation of progesterone receptor(s) in the uterus. J. Biol. Chem. 248: 6366-6374.

46. Frölich, J. C., T. W. Wilson, B. J. Sweetman, M. Smigel, A. S. Nies, K. Carr, J. T. Watson, and J. A. Oates. 1975 Urinary prostaglandins. Identification and origin. J. Clin. Invest. 55: 763-770.

47. Tobian, L., M. O'Donell, and P. Smith. 1974. Intrarenal prostaglandin levels during normal and high sodium intakes. Circ. Res. 34, 35(Suppl. I): 83-89.

48. Gimbrone, M. A., Jr., and R. W. Alexander. 1975. Angiotensin II stimulation of prostaglandin production in cultured human vascular endothelium. Science (Wash. D. C.). 189: 219-220.

49. Romero, J. C., C. L. Dunlap, and C. G. Strong. 1976. The effect of indomethacin and other anti-inflammatory drugs on the renin-angiotensin system. J. Clin. Invest. 58: $282-288$.

50. Nishikawa, L., A. Morrison, and P. Needleman. 1977. Exaggerated prostaglandin biosynthesis and its influence on renal resistance in the isolated hydronephrotic rabbit kidney. J. Clin. Invest. 59: 1143-1150.

51. Brown, J. J., and W. S. Peart. 1962. The effect of angiotensin on urine flow and electrolyte excretion in hypertensive patients. Clin. Sci. (Oxf.). 22: 1-17.

52. Hollenberg, N. K., G. H. Williams, B. Burger, W. Chenitz, I. Hoosmand, and D. F. Adams. 1976. Renal blood flow and its response to angiotensin II. An interaction between oral contraceptive agents, sodium intake and the renin-angiotensin system in healthy young women. Circ. Res. 38: 35-40.

53. White, M. G. 1972. Bartter's syndrome. A manifestation of renal tubular defects. Arch. Intern. Med. 129: 41-47. 